\title{
PENERAPAN MANAJEMEN KELAS DALAM PERKEMBANGAN SOSIAL DAN EMOSIONAL ANAK USIA DINI KELOMPOK A DI TK KEMALA BHAYANGKARI 47
}

\author{
Yulia Afandi ${ }^{1}$, Hani Ida Kusuma ${ }^{2}$, Lenny Nuraeni \\ ${ }^{1}$ Yulia Afandi, TK Kemala Bhayangkari 47 \\ ${ }^{2}$ Hani Ida Kusuma, PAUD Munggaran \\ ${ }^{3}$ Lenny Nuraeni, IKIP Siliwangi \\ ${ }^{1}$ afandiyulia@gmail.com, ${ }^{2}$ haniidakusuma@gmail.com, ${ }^{3}$ lennynuraeni86@gmail.com
}

\begin{abstract}
Yulia Afandi, et al. This research starts from the main problem that is about: "How the implementation of classroom management in improving emotional social development of early childhood in Group A TK Kemala Bhayangkari 47". The method used in this research is qualitative with descriptive method. This study intends to obtain empirical data about how the implementation of classroom management in improving social development of early childhood in Group A TK Kemala Bhayangkari 47. The authors define the method used in this research is descriptive method with the consideration that this method is a way researchers by describing events present or present. The results of the study were: 1) Implementation of Classroom Management in Emotional Social Development of Early Childhood in Kemala Bhayangkari Kindergarten 47 In the early childhood management class should be oriented to the characteristics of early childhood development. Understanding teachers about the characteristics of children will be useful in an effort to create a learning environment that supports child development. In general it can be said that the main guidance given to children include: In the organization of children in classes conducted in Kemala Bhayangkari Kindergarten 47 can be done by: Grouping children, Paired grouping (grouping in pairs), Multi grouping. 2) Implementation of Classroom Management in Developing Early Childhood Emotional Social in Kemala Bhayangkari Kindergarten 47 develops classroom management activities based on the understanding of learning concepts and developmentoriented and the characteristics of early childhood. 3) Supporting Factors and Inhibitors of Classroom Management Implementation in Developing Social and Emotional Early Childhood in Kemala Bhayangkari Kindergarten 47, among others: the supporting factors of class management manifestation are: a) Curriculum factors, b) Building factors and classroom facilities. The Inhibiting Factor Application of classroom management in developing social and emotional early childhood in kindergarten Kemala Bhayangkari 47, including: Physical environment factor, physical environment / learning place.

Keywords : the implementation of classroom management, social and emotional development of children.
\end{abstract}

ABSTRAK
Yulia Afandi, dkk. Penelitian ini bertitik tolak dari permasalahan pokok yaitu mengenai: “
Bagaimana Pelaksanaan manajemen kelas dalam meningkatkan perkembangan sosial
emosional anak usia dini di Kelompok A TK Kemala Bhayangkari 47”. Metode yang
digunakan dalam penelitian ini adalah kualitataif dengan metode deskriptif. Penelitian ini
bermaksud untuk memperoleh data empiris tentang bagaimana pelaksanaan majemen kelas
dalam meningkatkan perkembangan sosial anak usia dini di Kelompok A TK Kemala 


\section{JURNAL CERIA}

ISSN : 2614-6347 (Print) 2614-4107 (Online)

Vol.1 | No.3 | Mei 2018

Bhayangkari 47. Penulis menetapkan metode yang digunakan dalam penelitian ini adalah metode deskiptif dengan pertimbangan bahwa metode ini merupakan cara peneliti dengan menggambarkan peristiwa yang ada pada masa sekarang atau yang sedang terjadi. Hasil Penelitian diperoleh: 1) Pelaksanaan Manajemen Kelas dalam Mengembangkan Sosial Emosional Anak Usia Dini di TK Kemala Bhayangkari 47 Dalam Manajemen Kelas PAUD haruslah berorientasi pada karakteristik perkembangan anak usia dini. Pemahaman guru tentang karakteristik anak akan bermanfaat dalam upaya menciptakan lingkungan belajar yang mendukung perkembangan anak. Secara umum dapat dikatakan bahwa bimbingan utama yang diberikan kepada anak antara lain: Dalam pengorganisasian anak di kelas yang dilakukan di TK Kemala Bhayangkari 47 dapat dilakukan dengan : Pengelompokan anak, Paired grouping (pengelompokan secara berpasangan), Multi grouping. 2) Penerapan Manajemen Kelas Dalam Mengembangkan Sosial Emosional Anak Usia Dini di TK Kemala Bhayangkari 47 diantaranya mengembangkan kegiatan manajemen kelas yang di dasarkan pada pemahaman terhadap konsep belajar dan berorientasi pada perkembangan serta karakteristik anak usia dini. 3) Faktor Pendukung dan Penghambat Penerapan Manajemen Kelas Dalam Mengembangkan Sosial dan Emosional Anak Usia Dini di TK Kemala Bhayangkari 47, diantaranya: faktor pendukung perwujudan manajemen kelas yaitu: a) Faktor kurikulum, b) Faktor gedung dan sarana kelas. Adapun Faktor Penghambat Penerapan Manajemen kelas dalam mengembangkan sosial dan emosional anak usia dini di TK Kemala Bhayangkari 47, diantaranya: Faktor lingkungan fisik, lingkungan fisik/tempat belajar.

Kata Kunci: Penerapan Manajemen Kelas, Perkembangan Sosial dan Emosional Anak.

How to Cite: Afandi, Y., Kusuma, H.I., \& Nuraeni, L. (2018). PENERAPAN MANAJEMEN KELAS DALAM PERKEMBANGAN SOSIAL DAN EMOSIONAL ANAK USIA DINI KELOMPOK A DI TK KEMALA BHAYANGKARI 47. Ceria, 1 (3), 76-88. 


\section{PENDAHULUAN}

\section{Latar Belakang Masalah}

Pendidikan adalah usaha sadar bertujuan.Pendidikan pada hakekatnya adalah usaha membudayakan manusia atau memanusiakan manusia.Manusia itu sendiri adalah pribadi yang utuh dan pribadi yang kompleks sehingga sulit dipelajari secara tuntas. Oleh karena itu, masalah pendidikan tak akan pernah selesai, sebab hakekat manusia itu sendiri selalu berkembang mengikuti dinamika kehidupannya. Namun tidaklah berarti bahwa pendidikan harus berjalan secara alami. Pendidikan tetap memerlukan inovasi-inovasi sesuai dengan kemajuan ilmu pengetahuan dan teknologi tanpa mengabaikan nilai nilai manusia, baik sebagai makhluk sosial maupun sebagai makhluk religius (Nana Sudjana, 2009: 2) Dalam kaitannya dengan hal itu, maka kegiatan pendidikan merupakan suatu proses untuk mengubah sikap manusia dari suatu kondisi tertentu terhadap kondisi lainnya. Dengan kata lain, melalui pendidikan itu perubahan akan nampak dalam proses perubahan pikiran manusia, dari tidak mengerti menjadi mengerti, dari tidak mengetahui menjadi mengetahui.

Upaya meningkatkan kualitas pendidikan terus-menerus dilakukan, baik secara konvensional maupun inovatif. Hal tersebut lebih terfokus lagi dalam Undang-undang RI No.20 Tahun 2003 tentang Sistem Pendidikan Nasional pada BAB II, Pasal 3 yang berbunyi :

Pendidikan nasional berfungsi untuk mengembangkan kemampuan dan membentuk watak serta peradaban bangsa yang bermartabat dalam rangka mencerdaskan kehidupan bangsa dan bertujuan untuk mengembangkan potensi peserta didik agar menjadi manusia yang beriman dan bertaqwa kepada Tuhan Yang Maha Esa, berakhlak mulia, sehat, berilmu, cakap, kreatif, mandiri dan menjadi warga negara yang demokratis serta bertanggung-jawab.
Untuk meningkatkan mutu pendidikan diperlukan peningkatan dan penyempurnaan pendidikan, yang berkaitan erat dengan peningkatan mutu proses belajar mengajar secara operasional yang berlangsung di dalam kelas. Oleh karena itu, diperlukan manajemen kelas yang baik sehingga tujuan pembelajaran dapat tercapai. Karenanya, manajemen kelas memegang peranan yang sangat menentukan dalam proses belajar mengajar.

Manajemen sangat penting untuk diimplemntasikan dalam kegiatan di dalam kelas. Kebutuhan terhadap manajemen di kelas, bukan hanya karena kebutuhan akan efektifitas dan efesiensi proses pembelajaran melalui pengoptimalan fungsi kelas, namun lebih dari itu, manajemen di dalam kelas merupakan respon terhadap semakin meningkatnya tuntutan peningkatan kualitas pendidikan yang dimulai dari ruang kelas. Di ruang kelas, guru dituntut untuk mampu menghasilkan peserta didik yang utuh, sesuai fungsi pendidikan dalm undangundang sistem pendidikan nasional.

Manajemen kelas menurut Suharsimi Arikunto (1992: 67) adalah usaha yang dilakukan oleh guru membantu tercapainya kondisi yang optimal, sehingga terlaksananya kegiatan belajar seperti yang diharapkan. Adapun kegiatan manajemen kelas dapat diklasifikasikan menjadi dua, yaitu (1) yang memfokuskan pada hal-hal yang bersifat fisik, dan (2) yang memfokuskan pada hal-hal yang bersifat non-fisik.Kedua hal tersebut perlu dikelola secara baik dalam rangka menghasilkan suasana yang kondusif bagi terciptanya pembelajaran yang baik pula.

Hal-hal fisik yang perlu diperhatikan dalam manajemen kelas mencakup ; pengaturan ruang belajar dan perabot kelas, serta pengaturan peserta didik dalam belajar. Sedangkan hal-hal yang bersifat non-fisik lebih memfokuskan pada aspek interaksi peserta didik dengan peserta didik lainnya, peserta didik dengan guru dan lingkungan kelas maupun kondisi kelas menjelang, selama, dan akhir pembelajaran.Atas 
dasar inilah, maka hal-hal yang perlu diperhatikan dalam manajemen kelas adalah aspek psikologis, sosial dan hubungan interpersonal menjadi sangat dominan.

Sedangkan Euis Karwati (2014:67) berpendapat bahwa manajemen kelas merupakan masalah tingkah laku yang kompleks, dan guru menggunakannya untuk menciptakan dan mempertahankan kondisi kelas sedemikian rupa, sehingga siswa dapat mencapai tujuan pengajaran secara efisien dan memungkinkan mereka dapat belajar.

Usaha guru dalam menciptakan kondisi yang diharapkan akan efektif, apabila Pertama;diketahui secara tepat faktorfaktor mana sajakah yang dapat menunjang terciptanya kondisi yang menguntungkan dalam proses belajar mengajar. Kedua; diketahui masalah apa sajakah yang biasa timbul dan dapat merusak suasana belajarmengajar. Ketiga; dikuasainya berbagai pendekatan dalam manajemen kelas dan diketahui pula kapan dan untuk masalah mana suatu pendekatan tersebut digunakan.

Oleh karena itu, pengelola sekolah perlu menciptakan suasana gembira/ menyenangkan di lingkungan sekolah melalui manajemen kelas.Karena, dengan menjalin keakraban antara guru-siswa, maka guru dapat mengarahkan siswa dengan lebih mudah untuk mendorong dan memotivasi semangat belajar siswa.Disamping itu, juga dimaksudkan untuk menciptakan lingkungan belajar yang kondusif bagi peserta didik, sehingga tercapai tujuan pengajaran secara efektif dan efisien. Proses pembelajaran merupakan serangkaian kegiatan yang dilaksanakan oleh guru dan siswa dengan memanfaatkan sarana yang tersedia untuk memperoleh hasil belajar secara optimal.

Dalam kerangka inilah manejemen kelas dalam meningkatkan efektivitas proses belajar tampil sebagai upaya dalam meningkatkan mutu pendidikan melalui (1). Peningkatan kemandirian, fleksibilitas, partisipasi, keterbukaan, kerjasama, akuntabilitas, sustainbilitas, dan inisiatif sekolah dalam mengelola, memanfaatkan dan memberdayakan sumberdaya yang tersedia; (2). Meningkatkan kepedulian warga sekolah dan masyarakat dalam penyelenggaraan pendidikan melalui keputusan bersama; (3). Meningkatkan tanggung jawab sekolah kepada orangtua, masyarakat, dan pemerintah tentang mutu sekolahnya, dan (4). Meningkatkan kompetisi yang sehat antar sekolah tentang mutu pendidikan yang akan dicapai.

Jadi, Proses belajar mengajar dapat terwujud dengan baik apabila ada interaksi antara guru dan murid atau dengan media yang lainnya. Dengan kata lain belajar mengajar dikatakan efektif apabila adanya suatu interaksi antara guru dan siswa. Namun ada kendala yang dialami guru dalam melaksanakan kegiatan belajar mengajar, antara lain tingkat konsentrasi anak uisa dini, sehingga anak mudah sekali bosan dan tidak mau mengikuti kegiatan pembelajaran.Untuk menumbuhkan motivasi dan ketertarikan siswa pada saat pelajaran berlangsung guru dituntut mempunyai keahlian tertentu untuk dapat menciptakan suasana kelas yang mendukung proses belajar mengajar. Agar tercipta suasana kelas yang mendukung proses belajar mengajar yang nyaman, kondusif, komunikatif, serta dinamis diharapkan akan hasil belajar yang optimal dan semaksimal mungkin sesuai dengan tujuan dari pada pendidikan tersebut.

Berdasarkan uraian di atas, maka di identifikasikan manajemen kelas dan kemampuan mengajar guru erat kaitannya dengan proses dan hasil pembelajaran di sekolah tersebut. Sehingga peneliti tertarik untuk melakukan penelitian dengan judul :"Penerapan Manajemen Kelas Dalam Perkembangan Sosial dan Emosional Anak Usia Dini Pada Kelompok A di TK Kemala Bhayangkari 47'. 


\section{KAJIAN TEORITIK}

1. Konsep Manajemen Kelas

a. Pengertian Manajemen Kelas

Manajemen kelas terdiri dari dua kata, yaitu manajemen dan kelas. Manajemen merupakan rangkaian usaha untuk mencapai tujuan yang telah ditetapkan dengan memanfaatkan orang lain, sedangkan yang dimaksud dengan kelas adalah suatu kelompok orang yang melakukan kegiatan belajar bersama sesuai dengan tujuan yang telah ditetapkan, dalam kelas tersebut, guru berperan sebagai manajer utama dalam merecanakan, mengorganisasikan, mengaktualisasikan,dan melaksanakan pengawasan atau supervisi kelas..

b. Pendekatan dalam Manajemen Kelas

Terdapat berbagai pendekatan dalam manajemen kelas. Berikut ini disajikan beberapa pendekatan dalam manajemen kelas, diantaranya: Pendekatan Kekuasaan, Pendekatan Ancaman, Pendekatan Kebebasan, Pendekatan Resep, Pendekatan pengajaran, Pendekatan Perubahan Tingkah Laku, Pendekatan Sosial Emosional, Pendekatan kerja Kelompok, Pendekatan elektis (electic approach), Pendekatan Teknologi dan informasi.

3)Kegiatan Utama dalam Manajemen Kelas

a. Pengaturan peserta didik

b. Pengaturan fasilitas

c. Prinsip-prinsip Manajemen Kela

Prinsip-prinsip manajemen kelas yang dikembangkan oleh Syaiful Bahri Djamarah (2006: 185) terdiri dari :

a. Hangat dan Antusias

b. Tantangan

c. Bervariasi

d. Keluwesan

e. Penekanan hal yang positif

f. Penanaman kedisiplinan

c. Faktor-faktor yang mempengaruhi manajemen kelas:

a. Lingkungan fisik

b. Kondisi sosio-emosional

c. Kondisi organisasional
2. Konsep Perkembangan Sosial -Emosi

1) Pengertian Perkembangan Sosial

Menurut Plato secara potensial (fitrah) manusia dilahirkan sebagai makhluk sosial (zoon politicori). Syamsuddin (2003:105) mengungkapkan bahwa "sosialisasi adalah proses belajar untuk menjadi makhluk sosial", sedangkan menurut Loree (1970:86) "sosialisasi merupakan suatu proses di mana individu (terutama) anak melatih kepekaan dirinya terhadap rangsangan-rangsangan sosial terutama tekanan-tekanan dan tuntutan kehidupan (kelompoknya) serta belajar bergaul dengan bertingkah laku, seperti orang lain di dalam lingkungan sosialnya".

Muhibin Syah (1999:35) mengatakan bahwa perkembangan sosial merupakan proses pembentukan social self(pribadi dalam masyarakat), yakni pribadi dalam keluarga, budaya, bangsa, dan seterusnya. Adapun Hurlock (1978:250) mengutarakan bahwa perkembangan sosial merupakan perolehan kemampuan berperilaku yang sesuai dengan tuntutan sosial. "Sosialisasi adalah kemampuan bertingkah laku sesuai dengan norma, nilai atau harapan sosial".

2) Perkembangan Emosi

Abin Syamsuddin (2003:69) mengemukakan bahwa "emosi merupakan suatu suasana yang kompleks (a complex feeling state) dan getaran jiwa (stid up state)yang menyertai atau muncul sebelum atau sesudah terjadinya suatu perilaku". Berdasarkan definisi di atas kita dapat memahami bahwa emosi merupakan suatu keadaan yang kompleks, dapat berupa perasaan ataupun getaran jiwa yang ditandai oleh perubahan biologis yang muncul menyertai terjadinya suatu perilaku.

3) Proses Perkembangan Sosial Anak Usia Dini

Untuk menjadi individu yang mampu bermasyarakat diperlukan tiga proses sosialisasi. Proses sosialisasi ini tampaknya terpisah, tetapi sebenarnya saling berhubungan satu sama 
lainnya, sebagaimana yang dikemukakan oleh Hurlock (1978), yaitu sebagai berikut.

a. Belajar untuk bertingkah laku dengan cara yang dapat diterima masyarakat.

b. Belajar memainkan peran sosial yang ada di masyarakat.

c. Mengembangkan sikap/tingkah laku sosial terhadap individu lain dan aktivitas sosial yang ada di masyarakat.

4) Fungsi dan Peranan Emosi Pada Perkembangan Anak Usia Dini

Setelah kita mengetahui apa dan bagaimana mekanisme terjadinya emosi pada individu, selanjutnya kita akan membahas tentang tungsi atau peranan emosi pada perkembangan anak. Fungsi dan peranan yang dimaksud adalah sebagai berikut.

a. Merupakan bentuk komunikasi sehingga anak dapat menyatakan segala kebutuhan dan perasaannya pada orang lain..

b. Emosi berperan dalam mempengaruhi kepribadian dan penyesuaian diri anak dengan lingkungan sosialnya.

\section{B. Konsep Pendidikan Anak Usia Dini}

a. Pengertian dan Karakteristik AUD

Anak usia dini adalah anak yang baru dilahirkan sampai usia 6 tahun. Usia ini merupakan usia yang sangat menentukan dalam pembentukan karakter dan kepribadian anak (Yuliani Nurani Sujiono, 2009: 7). Usia dini merupakan usia di mana anak mengalami pertumbuhan dan perkembangan yang pesat. Usia dini disebut sebagai usia emas (golden age). Makanan yang bergizi yang seimbang serta stimulasi yang intensif sangat dibutuhkan untuk pertumbuhan dan perkembangan tersebut.

Ada berbagai kajian tentang hakikat anak usia dini, khususnya anak TK diantaranya oleh Bredecam dan Copple, Brener, serta Kellough (dalam Masitoh dkk., 2005: 1.12 - 1.13) sebagai berikut.

a. Anak bersifat unik.

b. Anak mengekspresikan perilakunya secara relatif spontan.

c. Anak bersifat aktif dan enerjik.

d. Anak itu egosentris.

e. Anak memiliki rasa ingin tahu yang kuat dan antusias terhadap banyak hal.

f. Anak bersifat eksploratif dan berjiwa petualang.

g. Anak umumnya kaya dengan fantasi.

h. Anak masih mudah frustrasi.

i. Anak masih kurang pertimbangan dalam bertindak.

j. Anak memiliki daya perhatian yang pendek.

k. Masa anak merupakan masa belajar yang paling potensial.

1. Anak semakin menunjukkan minat terhadap teman

b. Prinsip-Prinsip Perkembangan AUD

Prinsip-prinsip perkembangan anak usia dini berbeda dengan prinsip-prinsip perkembangan fase kanak-kanak akhir dan seterusnya. Adapun prinsip-prinsip perkembangan anak usia dini menurut Bredekamp dan Coople (Siti Aisyah dkk., 2007) adalah sebagai berikut.

a. Perkembangan aspek fisik, sosial, emosional, dan kgnitif anak saling berkaitan dan saling mempengaruhi satu sama lain.

b. Perkembangan fisik/motorik, emosi, social, bahasa, dan kgnitif anak terjadi dalam suatu urutan tertentu yang relative dapat diramalkan.

c. Perkembangan berlangsung dalam rentang yang bervariasi antar anak dan antar bidang pengembangan dari masingmasing fungsi.

d. Pengalaman awal anak memiliki pengaruh kumulatif dan tertunda terhadap perkembangan anak. 
e. Perkembangan anak berlangsung ke arah yang makin kompleks, khusus, terorganisasi dan terinternalisasi.

f. Perkembangan dan cara belajar anak terjadi dan dipengaruhi oleh konteks social budaya yang majemuk.

g. Anak adalah pembelajar aktif, yang berusaha membangun pemahamannya tentang tentang lingkungan sekitar dari pengalaman fisik, social, dan pengetahuan yang diperolehnya.

h. Perkembangan dan belajar merupakan interaksi kematangan biologis dan lingkungan, baik lingkungan fisik maupun lingkungan sosial.

i. Bermain merupakan sarana penting bagi perkembangan social, emosional, dan kognitif anak serta menggambarkan perkembangan anak.

j. Perkembangan akan mengalami percepatan bila anak berkesempatan untuk mempraktikkan berbagai keterampilan yang diperoleh dan mengalami tantangan setingkat lebih tinggi dari hal-hal yang telah dikuasainya.

k. Anak memiliki modalitas beragam (ada tipe visual, auditif, kinestetik, atau gabungan dari tipe-tipe itu) untuk mengetahui sesuatu sehingga dapat belajar hal yang berbeda pula dalam memperlihatkan hal-hal yang diketahuinya.

1. Kondisi terbaik anak untuk berkembang dan belajar adalam dalam komunitas yang menghargainya, memenuhi kebutuhan fisiknya, dan aman secara fisik dan fisiologis.

c. Tujuan Pendidikan Anak Usia Dini

Secara umum tujuan pendidikan anak usia dini adalah mengembangkan berbagai potensi anak sejak dini sebagai persiapan untuk hidup dan dapat menyesuaikan diri dengan lingkungannya.
Secara khusus tujuan pendidikan anaka usia dini adalah (Yuliani Nurani Sujiono, 2009: 42 - 43):

a. Agar anak percaya akan adanya Tuhan dan mampu beribadah serta mencintai sesamanya.

b. Agar anak mampu mengelola keterampilan tubuhnya termasuk gerakan motorik kasar dan motorik halus, serta mampu menerima rangsangan sensorik.

c. Anak mampu menggunakan bahasa untuk pemahaman bahasa pasif dan dapat berkomunikasi secara efektif sehingga dapat bermanfaat untuk berpikir dan belajar.

d. Anak mampu berpikir logis, kritis, memberikan alasan, memecahkan masalah dan menemukan hubungan sebab akibat.

e. Anak mampu mengenal lingkungan alam, lingkungan social, peranan masyarakat dan menghargai keragaman sosial dan budaya serta mampu mngembangkan konsep diri yang positif dan control diri.

f. Anak memiliki kepekaan terhadap irama, nada, berbagai bunyi, serta menghargai karya kreatif.

4. Prinsip-Prinsip Pendidikan Anak Usia Dini

Pendidikan anak usia dini pelaksanaannya menggunakan prinsip-prinsip (Forum PAUD, 2007) sebagai berikut.: Berorientasi pada Kebutuhan Anak, Belajar melalui bermain, Menggunakan lingkungan yang kondusif, Menggunakan pembelajaran terpadu, Mengembangkan berbagai kecakapan hidup, Menggunakan berbagai media edukatif dan sumber belajar, Menggunakan berbagai media edukatif dan sumber belajar.

\section{METODOLOGI PENELITIAN}

Metode merupakan hal yang sangat penting diperlukan dalam suatu penelitian dengan tujuan 
untuk memandu seseorang peneliti. Suatu penelitian akan efektif dalam mencapai tujuannya sesuai dengan yang diharapkan apabila memperhatikan metode yang akan digunakan, seperti yang dikemukakan oleh Nazir (2009:31) bahwa metode penelitian akan memandu seorang peneliti mengenai urutanurutan bagaimana penelitian dilakukan. Kemudian Surachmad (1998:131) mengemukakan bahwa metode merupakan cara utama yang dipergunakan untuk mencapai tujuan.

Penelitian ini bermaksud untuk memperoleh data empiris tentang Penerapan manajemen kelas dalam perkembangan sosial emosional AUD di TK Kemala Bhayangkari 47, maka untuk mencapai tujuan tersebut penelitian ini menggunakan pendekatan kualitatif.

\section{HASIL PENELITIAN DAN PEMBAHASAN}

1. Gambaran Umum Lokasi Penelitian

Pada bagian ini penulis akan menyajikan hal-hal yang berkaitan dengan deskripsi data dan hasil penelitian. Adapun pokok-pokok pembahasannya meliputi gambaran umum lokasi penelitian, gambaran umum responden penelitian, deskripsi hasil penelitiandan pembahasan hasil penelitian. Adapun lokasi tempat penelitian dilaksanakan di TK Kemala Bhayangkari 47 yang beralamat di Komplek SPN POLDA JABARJl. Kolonel Masturi No. 110 RT 005 RW 012 Desa Jambudipa Kecamatan Cisarua Kab. Bandung Barat Prop. Jawa Barat..

2. Hasil Penelitian dan Pembahasan

1) Pelaksanaan Manajemen Kelas dalam Mengembangkan Sosial Emosional Anak Usia Dini di TK Kemala Bhayangkari 47?

Dalam Manajemen Kelas PAUD haruslah berorientasi pada karakteristik perkembangan anak usia dini. Pemahaman guru tentang karakteristik anak akan bermanfaat dalam upaya menciptakan lingkungan belajar yang mendukung perkembangan anak. Secara umum dapat dikatakan bahwa bimbingan utama yang diberikan kepada anak antara lain :

Mengorganisasi anak Anak-anak yang baru pertama kali masuk sekolah biasanya masih terbawa oleh kebiasaan atau ritme kehidupannya dirumah. Untuk hal tersebut guru melakukan organisasi terhadap anak dan orang dewasa lain sehingga terbentuk suatu sistem kerja sama yang baik antar anak dengan orang dewasa atau guru. Anak-anak juga perlu dibantu untuk belajar mempelajari berbagai ketrampilan interaksi sosial yang positif yang akan mereka butuhkan. Dalam pengorganisasian anak di kelas yang dilakukan di TK Kemala Bhayangkari 47 dapat dilakukan dengan :

a) Pengelompokan anak Melalui pengelompokan yang dilakukan guru, anak dapat bekerja lebih baik dari pada bekerja sendiri, anak dapat saling belajar dari reaksi masing-masing anak, bahkan mereka dapat belajar melalui model yang ditunjukkan oleh anak lain. Dalam 1 kelompok terdapat 4 atau 5 anak, dengan seperti itu anak akan lebih mudah memperoleh respon verbal dan fisik dari guru. Open grouping. Dalam open grouping, anak memilih kelompok berdasarkan minat. Dalam tipe ini anak dituntut untuk dapat mengantisipasi kegiatan yang akan diikutinya, yakni merencanakan pilihannya, serta memilih adalah suatu kegiatan dari kegiatankegiatan yang lainnya.

b) Paired grouping (pengelompokan secara berpasangan) Dalam pengelompokan ini anak bekerja sejenak dengan anak lain dan saling membantu. Dengan demikian diharapkan semua anak saling belajar dan mengajar karena mereka setiap anak memiliki kekuatan dan kebutuhan satu sama lain saling melengkapi.

c) Multi grouping Dalam kelompok ini terdiri dari beberapa anak yang usianya bervariasi. 
Dalam kelompok ini anak-anak diharapkan saling membantu, yang besar melindungi yang kecil, berbagi, membimbing, dan saling mengajarkan sesuatu.

1) Pemanfaatan anak dalam proses mengajar yang lebih luas Di dalam kelas manapun, sebaiknya anak mendapat kesempatan beberapa tanggungjawab yang merupakan tugas dalam kelas, misalnya,

2) Menyimpan atau meletakkan kembali pada tempatnya alat permainan atau materi yang baru saja dipergunakan, serta tetap menjaga kebersihan dan kerapian kelas.

3) Tata laksana kelas Tata laksana kelas dipusatkan dalam aturan di dalam kelas. Masing-masing guru seringkali mempunyai cara, pendekatan, prioritas yang berbeda dalam melaksanakan tugasnya dalam kelas.

Batasan terhadap lingkungan Sesuatu yang harus dilakukan untuk membatasi tingkah laku anak yang berlebihan. Misalnya membantu anak agar ia menjadi orang yang diterima lingkungannya, membantu anak membedakan tingkah laku yang dapat diterima dan yang tidak diterima.

Manajemen lingkungan fisik Manajemen lingkungan belajar pada level TK atau prasekolah di antara pembagian paling populer adalah membagi lingkungan belajar kedalam dua bagian besar yaitu : a. Manajemen lingkungan dalam kelas (Indoor) Kelas yang baik merupakan lingkungan belajar yang bersifat menantang dan merangsang anak untuk belajar, memberikan rasa aman dan kepuasan kepada anak dalam mencapai tujuan belajarnya. Ruang kelas anak prasekolah biasanya merupakan kelas yang diorganisasikan sesuai dengan pusat-pusat kegiatan. Masing-masing pusat kegiatan memiliki program tertentu. Pusat kegiatan tersebut selalu berorientasi pada anak sebagai pusat bukan orang dewasa. Setiap kali diharapkan agar anak selalu aktif dalam mengikuti kegiatan baik yang bersifat kelompokkelompok besar, kecil ataupun dalam kegiatan individual. Dalam hal ini umumnya terdapat bebarapa pusat kegiatan, diantaranya : 1) sentra kegiatan seni dan pekerjaan tangan 2) sentra bermain drama 3) sentra penyusunan balok 4) sentra memanipulasi materi 5) sentra musik 6) Pusat pameran Pusat-pusat tersebut dapat disesuaikan dengan minat anak atau tema yang ada. Selain pusat kegiatan Manajemen Kelas juga meliputi penataan ruangan maupun pengorganisasian peserta didik sesuai dengan kebutuhan dan program yang direncanakan akan membantu pencapaian standar kompetensi dan kompetensi dasar, serta tujuan pembelajaran secara optimal.

\section{2) Penerapan ManajemenKelasDalam}

Mengembangkans

SosialDanEmosionalAnakUsiaDini di TK Kemala Bhayangkari 47?

KegiatanManajemenKelasharusdidasarkanpadap emahamanterhadapkonsepbelajardanberorientasi padaperkembangansertakarakreristikanakusia TK.

Keadaaniniakanmemberikankonstribusibagianak dalambelajarsehinggamerekadapatberkembangse cara optimal sesuaipotensi yang dimilikinya. SehubungandenganituBredekampdanRosegantm enjelaskanbahwaanakakanbelajardenganbaikdan bermaknaapabila

:Anakmerasaamansecarapsikologissertakebutuha nkebutuhanfisiknyaterpenuhi.

Anakbelajarmelaluiinteraksisosialdengan orang dewasadananaklainnya.

Kegiatanbelajarmerefleksikansuatulingkaran

yang takpernahputus yang mulaidengankesadarankemudianberalihkeeksplo rasi, pencarian, danakhirnyapenggunaan, 4 . Anakbelajarmelaluibermain. 5 . Minatdankebutuhananakterpenuhi 6. Unsurvariasi individual anakdiperhatikan. Perkembangansosialemosionalmeliputiperkembangandalamhalemosi, kepribadian, danhubungan 
interpersonal.SelamatahunKanak-kanakawal, perkembangansosial-emosionalberkisartentang proses sosialisasi, yaitu proses ketikaanakmempelajarinilai-nilaidanperilaku yang diterimadarimasyarakat. Padausiatersebut, terdapattigatujuandalamperkembangansosialemo sional, yaitu : a) Mencapai sense of self ataupemahamandirisendirisertaberhubungandeng an orang lain. b)

Bertanggungjawabterhadapdirisendirimeliputike mampuanuntukmengikutiaturandanrutinitas, menghargai orang lain, danmengambilinisiatif. c) Manampilkanperilakusosial, sepertiempati, berbagi, danmenunggugiliran.

3) Faktor Pendukung dan PenghambatPenerapanManajemenKelasDala $\mathrm{m} \quad$ Mengembangkan SosialdanEmosionalAnakUsiaDini di TK Kemala Bhayangkari 47?

Berhasilnyamanajemenkelasdalammemberikand ukunganterhadappencapaiantujuanpembelajaran yang banyakdipengaruhiolehberbagaifaktor.

Beberapafaktor akandicapai, perwujudanManajemenKelasyaitu:

a) FaktorKurikulumKarenakegiatankelasbukans ekedardipusatkanpadapenyampaiansejumlah materipelajaran, akantetapijugamemperhatikanaspekpembent ukanpribadi.

UntukitukurikulumkaitannyadenganManaje menKelasharusdirancangsebagaipengalaman edukatif yang dirancangsekolahdalammembantuanakmenca paitujuanpendidikannya.

b) FaktorgedungdansaranakelasDalamkonteksin idiperlukankreatifitasdalammengaturdanmen dayagunakansarana/gedung yang bersediaberdasarkankurikulum yang dipergunakan

Adapun Faktor Penghambat

Penerapanmanajemenkelasdalam

mengembangkan sosialdanemosionalanakusiadini di TK Kemala Bhayangkari 47, yaitu: Faktor lingkungan fisik Lingkungan fisik/tempat belajar masih terbatas. Faktor lingkungan fisik ini mempunyai pengaruh penting terhadap hasil pembelajaran. Lingkungan fisik yang menguntungkan dan memenuhi syarat minimal mendukung meningkatnya intensitas proses pembelajaran. Adapun kondisi fisik di TK Kemala Bhayangkari 47 ini meliputi: Ruangan tempat berlangsunya proses belajar mengajar, Pengaturan tempat duduk, ventilasi dan pengaturan cahaya, Pengaturan penyimpanan barang-barang.

\section{KESIMPULAN DAN SARAN}

\section{A. Kesimpulan}

1) Pelaksanaan Manajemen Kelas dalam Mengembangkan Sosial Emosional Anak Usia Dini di TK Kemala Bhayangkari 47?

Dalam Manajemen Kelas PAUD haruslah berorientasi pada karakteristik perkembangan anak usia dini. Pemahaman guru tentang karakteristik anak akan bermanfaat dalam upaya menciptakan lingkungan belajar yang mendukung perkembangan anak. Secara umum dapat dikatakan bahwa bimbingan utama yang diberikan kepada anak antara lain :

Mengorganisasi anak Anak-anak yang baru pertama kali masuk sekolah biasanya masih terbawa oleh kebiasaan atau ritme kehidupannya dirumah. Untuk hal tersebut guru melakukan organisasi terhadap anak dan orang dewasa lain sehingga terbentuk suatu sistem kerja sama yang baik antar anak dengan orang dewasa atau guru. Anak-anak juga perlu dibantu untuk belajar mempelajari berbagai ketrampilan interaksi sosial yang positif yang akan mereka butuhkan. Dalam pengorganisasian anak di kelas yang dilakukan di TK Kemala Bhayangkari 47 dapat dilakukan dengan :

a) Pengelompokan anak Melalui pengelompokan yang dilakukan guru, anak dapat bekerja lebih baik dari pada bekerja 
sendiri, anak dapat saling belajar dari reaksi masing-masing anak, bahkan mereka dapat belajar melalui model yang ditunjukkan oleh anak lain. Dalam 1 kelompok terdapat 4 atau 5 anak, dengan seperti itu anak akan lebih mudah memperoleh respon verbal dan fisik dari guru. Open grouping. Dalam open grouping, anak memilih kelompok berdasarkan minat. Dalam tipe ini anak dituntut untuk dapat mengantisipasi kegiatan yang akan diikutinya, yakni merencanakan pilihannya, serta memilih adalah suatu kegiatan dari kegiatan-kegiatan yang lainnya.

b) Paired grouping (pengelompokan secara berpasangan) Dalam pengelompokan ini anak bekerja sejenak dengan anak lain dan saling membantu. Dengan demikian diharapkan semua anak saling belajar dan mengajar karena mereka setiap anak memiliki kekuatan dan kebutuhan satu sama lain saling melengkapi.

c) Multi grouping Dalam kelompok ini terdiri dari beberapa anak yang usianya bervariasi.

Dalam kelompok ini anak-anak diharapkan saling membantu, yang besar melindungi yang kecil, berbagi, membimbing, dan saling mengajarkan sesuatu.

a) Pemanfaatan anak dalam proses mengajar yang lebih luas Di dalam kelas manapun, sebaiknya anak mendapat kesempatan beberapa tanggungjawab yang merupakan tugas dalam kelas, misalnya,

b) Menyimpan atau meletakkan kembali pada tempatnya alat permainan atau materi yang baru saja dipergunakan, serta tetap menjaga kebersihan dan kerapian kelas.

c) Tata laksana kelas Tata laksana kelas dipusatkan dalam aturan di dalam kelas. Masing-masing guru seringkali mempunyai cara, pendekatan, prioritas yang berbeda dalam melaksanakan tugasnya dalam kelas.
Batasan terhadap lingkungan Sesuatu yang harus dilakukan untuk membatasi tingkah laku anak yang berlebihan. Misalnya membantu anak agar ia menjadi orang yang diterima lingkungannya, membantu anak membedakan tingkah laku yang dapat diterima dan yang tidak diterima.

Manajemen lingkungan fisik Manajemen lingkungan belajar pada level TK atau prasekolah di antara pembagian paling populer adalah membagi lingkungan belajar kedalam dua bagian besar yaitu : a. Manajemen lingkungan dalam kelas (Indoor) Kelas yang baik merupakan lingkungan belajar yang bersifat menantang dan merangsang anak untuk belajar, memberikan rasa aman dan kepuasan kepada anak dalam mencapai tujuan belajarnya. Ruang kelas anak prasekolah biasanya merupakan kelas yang diorganisasikan sesuai dengan pusat-pusat kegiatan. Masing-masing pusat kegiatan memiliki program tertentu. Pusat kegiatan tersebut selalu berorientasi pada anak sebagai pusat bukan orang dewasa. Setiap kali diharapkan agar anak selalu aktif dalam mengikuti kegiatan baik yang bersifat kelompokkelompok besar, kecil ataupun dalam kegiatan individual. Dalam hal ini umumnya terdapat bebarapa pusat kegiatan, diantaranya : 1) sentra kegiatan seni dan pekerjaan tangan 2) sentra bermain drama 3) sentra penyusunan balok 4) sentra memanipulasi materi 5) sentra musik 6) Pusat pameran Pusat-pusat tersebut dapat disesuaikan dengan minat anak atau tema yang ada. Selain pusat kegiatan Manajemen Kelas juga meliputi penataan ruangan maupun pengorganisasian peserta didik sesuai dengan kebutuhan dan program yang direncanakan akan membantu pencapaian standar kompetensi dan kompetensi dasar, serta tujuan pembelajaran secara optimal.

2) Penerapan ManajemenKelasDalam Mengembangkans Sosial Dan Emosional Anak Usia Dini di TK Kemala Bhayangkari 47 ? 
Kegiatan Manajemen Kelas harus didasarkan pada pemahaman terhadap konsep belajar dan berorientasi pada perkembangan serta karakreristik anak usia TK. Keadaan ini akan memberikan konstribusi bagi anak dalam belajar sehingga mereka dapat berkembang secara optimal sesuai potensi yang dimilikinya. Sehubungan dengan itu Bredekamp dan Rose gant menjelaskan bahwa anak akan belajar dengan baik dan bermakna apabila Anak merasa aman secara psikologis serta kebutuhankebutuhan fisiknya terpenuhi. 2. Anak belajar melalui interaksi sosial dengan orang dewasa dan anak lainnya. 3. Kegiatan belajar merefleksikan suatu lingkaran yang tak pernah putus yang mulai dengan kesadaran kemudian beralih ke eksplorasi, pencarian, dan akhirnya penggunaan, 4. Anak belajar melalui bermain. 5. Minat dan kebutuhan anak terpenuhi 6. Unsur variasi individual anak diperhatikan.

Perkembangan sosial-emosional meliputi perkembangan dalam hal emosi, kepribadian, dan hubungan interpersonal.Selama tahun Kanak-kanak awal, perkembangan sosialemosional berkisa rtentang proses sosialisasi, yaitu proses ketika anak mempelajari nilai-nilai dan perilaku yang diterima dari masyarakat. Pada usia tersebut, terdapat tiga tujuan dalam perkembangan sosial emosional, yaitu : a) Mencapai sense of self atau pemahaman diri sendiri serta berhubungan dengan orang lain. b) Bertanggung jawab terhadap diri sendiri meliputi kemampuan untuk mengikuti aturan dan rutinitas, menghargai orang lain, dan mengambil inisiatif. c) Manampilkan perilaku sosial, sepert iempati, berbagi, dan menunggu giliran.

3) Faktor Pendukung dan Penghambat Penerapan Manajemen Kelas Dalam Mengembangkan Sosial dan Emosional Anak Usia Dini di TK Kemala Bhayangkari 47 ?

Berhasilnya manajemen kelas dalam memberikan dukungan terhadap pencapaian tujuan pembelajaran yang akan dicapai, banyak dipengaruhi oleh berbagai faktor. Beberapa faktor pendukung perwujudan Manajemen Kelas yaitu:

a) Faktor Kurikulum Karena kegiatan kelas bukan sekedar dipusatkan pada penyampaian sejumlah materi pelajaran, akan tetapi juga memperhatikan aspek pembentukan pribadi. Untuk itu kurikulum kaitannya dengan Manajemen Kelas harus dirancang sebagai pengalaman edukatif yang dirancang sekolah dalam membantu anak mencapai tujuan pendidikannya.

b) Faktor gedung dan sarana kelas. Dalam konteks ini diperlukan kreatifitas dalam mengatur dan mendayagunakan sarana/gedung yang bersedia berdasarkan kurikulum yang dipergunakan

Adapun Faktor Penghambat Penerapan manajemen kelas dalam mengembangkan sosial dan emosional anak usia dini di TK Kemala Bhayangkari 47 adalah Faktor lingkungan fisik Lingkungan fisik/tempat belajar masih terbatas. Faktor lingkungan fisik ini mempunyai pengaruh penting terhadap hasil pembelajaran. Lingkungan fisik yang menguntungkan dan memenuhi syarat minimal mendukung meningkatnya intensitas proses pembelajaran. Adapun kondisi fisik di TK Kemala Bhayangkari 47 ini meliputi: Ruangan tempat berlangsunya proses belajar mengajar, Pengaturan tempat duduk, ventilasi dan pengaturan cahaya, Pengaturan penyimpanan barang-barang.

\section{DAFTAR PUSTAKA}

Aisyah, Siti dkk. (2007). Perkembangan dan Konsep Dasar Pengembangan Anak Usia Dini. Jakarta: Universitas Terbuka

Arikunto, S. (1992). Manajemen Kelas. Jakarta: Rineka Cipta.

Djamarah, S. B. (2006). Strategi Belajar Mengajar. Jakarta: Rineka Cipta 
ISSN : 2614-6347 (Print) 2614-4107 (Online)

Vol.1 | No.3 | Mei 2018

Hurlock. (1978). Perkembangan Anak. Jakarta: Erlangga.

Karwati, Euis dan Priansa, Donni. (2014). Manajemen Kelas. bandung: Alfabeta

Loree, MR. (1970). Psychology Belajar. Ciputat: Logos Wacana Ilmu

Masitoh, dkk. (2005) StrategiPembelajaran TK. Jakarta: 2005

Nazir, M. (2009).MetodePenelitian. Jakarta: Ghalia Indonesia.

Sudjana, N. (2009). Penelitian dan Penilaian Pendidikan. Bandung: Sinar Baru Algesindo.

Sujiono, Yuliani Nurani. (2009) Konsep Dasar Pendidikan Anak Usi aDini. Jakarta: PT Indeks

Surachmad, W. (1998). Metode Penelitian Sosial. Bandung: Tarsito

Syah, M. (1999).Psikologi Belajar. Jakarta:PT. Raja Grafindo.

Syamsudin, A. (2003). Psikologi Pendidikan. Bandung: PT. Rosda Karya.

Undang-Undang Nomor 20 Tahun 2003 tentang Sistem Pendidikan Nasional. Jakarta: Depdiknas 


\section{JURNAL CERIA}

ISSN : 2614-6347 (Print) 2614-4107 (Online)

Vol.1 | No.3 | Mei 2018 